\title{
Talent Management to Competitive Advantage Rattan Furniture Industry: A Case of Cirebon, Indonesia
}

\author{
A. Ciptagustia \\ Department of Management, Universitas Pendidikan Indonesia \\ Bandung, INDONESIA \\ annisacipta@upi.edu
}

\begin{abstract}
- this study aims to describe the talent management and competitive advantage [1], explore the influence of Talent Management to Competitive Advantage of rattan furniture industry [2]. The data were analyzed by simple regression analysis. In this research, furniture rattan company member ASMINDO Cirebon was chosen as the analysis unit and 70 company's samples selected using proportional random sampling. The research findings show that The level of talent management of the rattan furniture industry member ASMINDO Cirebon is categorized in average level [1], the rattan furniture industry members of ASMINDO Cirebon competitive advantage is rooted in employee productivity growth indicators [2], The level of competitive advantage of rattan furniture industry Cirebon is positively influenced by the typical talent management [3].
\end{abstract}

Keywords-competitive advantage, talent management, rattan furniture industry

\section{INTRODUCTION}

Indonesia is the largest country that produces rattan in the world, an estimated $80 \%$ of rattan raw materials in the world is produced by Indonesia which are spread on the island of Borneo, Sumatra, Sulawesi and Papua island with a production rate of about 622000 tons / year (Indonesia Rattan Foundation). However, on the contrary, the processing industry, especially rattan wicker furniture, is still unable to compete with China and Italy in the world market share where China won $20.72 \%$, Italy got $17.71 \%$ and Indonesia only controlled $7.86 \%$ [1].

This situation was reflected by a decrease in the performance of national rattan furniture. The Commerce Department data show that in 2004 to 2009, rattan furniture export was also decreased by $45 \%$. Still in the same year, the total installed capacity of finished rattan products (rattan furniture) and realization of production were decreased $30 \%$ in the following 4 years. As a result, the number of rattan industries was decreasing, which as of December 2009 a total of 220 companies (43\%) were out of business, 208 companies (40\%) were in poor condition and 136 companies (17\%) survived [2]. One of the biggest producer of rattan furniture is Cirebon, so the decline in the volume and value of national exports is affected by the performance of production in Cirebon [3].

Many believe that the problem was due to government regulations that decided to reopen the export of raw rattan in 2005 through a decree of the Minister of Trade No. 12 / M-
DAG / PER / 6/2005 on the export of rattan. This was turning rattan furniture industry. However, based on the results of field research conducted by the Commission in Cirebon, rattan business operators stated that they had never encountered difficulties in obtaining raw materials of rattan cane from farmers and traders in Sumatra, Kalimantan, and Sulawesi. Thus, it can be seen that the amount of domestic production of cane was so much more influenced by market conditions / demand for furniture products overseas, because $80 \%$ of the market demand for rattan furniture came from abroad [4].

In accordance with the results of interviews with the secretary of the Association of Indonesian Furniture (ASMINDO) in Cirebon, the cause of the problems of low competitiveness of national rattan furniture is because the products are not competitive enough with both of the products design and prices offered. Then, the other cause is the shortage of skilled labor for both designers and craftsmen (Interview with the owner of CV. Larissa 2013). From this phenomenon, it seems that competitive advantage can be determined by the company because the company's resource is a source of competitive advantage.

Resource-based view (RBV) can answer the problems because the source of competitive advantage is not only static resources but also the exploitation of what is owned by the company in the form of unique skills, technology and knowledge, or is derived from internal sources called insideout perspective [5] [6]. However, not all of the resources and capability can yield competitive advantage. Resources that can provide competitive advantage must be valuable, rare, and imperfectly imitable and non-substitutable (VRIN) [7] [8].

\section{THEORETICAL FRAMEWORK}

[9] This study uses RBV perspective. According to Armstrong (2006), RBV is one of the strategic management approaches. But in the current development, the theory of RBV has been widely used in the strategic management approach of human resources because sustainable competitive advantage is the combination of resources and capabilities that become a source of excellence achieved continuously through the implementation of unique and proper strategies so that it will be difficult to be implemented or replicated by competitors. As the constituent elements derived from internal sources, then it will not be separated from the study of Human Resources Management since intangible assets and capabilities are derived from the human resources management (HRM). These 
influences on the indicators in measuring ownership of sustainable competitive advantage for the company. The result will change the indicator in the measurement of sustainable competitive advantage which use the output of strategic management and human resource management or strategic management of human resources.

In the scientific study of human resource management, a company that has a sustainable competitive advantage must have a high effectiveness, be able to meet the interests of the stakeholders of its human resources, customers, shareholders, or the surrounding community. In addition, effective company also has high employee productivity. In a study of strategic management, sustainable competitive advantage, the company's performance, the superior performance of the company and the reputation obtained from the consumer are the company's success so, according Spanos and Lioukas (2001) if the company has a sustainable competitive advantage, they are a successful company over competitors as seen from some indicators namely profit, market share and sales trends [10]. Kusumawati (2010) stated that the company's performance is determined in two dimensions, namely financial indicators and growth such as sales growth, profit growth, the growth of new products, the productivity of employees [11].

It is being debated for the measurement of sustainable competitive advantage. [12] According to Ferdinand (2003), there will be indicators of sustainable competitive advantage that refers to the perspective of RBV if the company had previously discovered a key resource to the indicator [12], namely (1) Durability (superior resources and performance is measured by how to survive the superiority of assets of strategic compete and performance success), (2) immutability (show the ability to imitate a key resource companies that measured the degree to which the competitor is deemed realize that it is very difficult to replicate the advantages of the company). (3) Ease of equaling impersonation shows the ease of competitors to match what is imitated is measured by the degree of convenience for a competitor to match the key strategic assets owned by the company. However, by Barney and Clark (2007), the competitive advantage is when a company is able to generate more economic value than corporate profits in the industry and sustainable competitive advantage is when a company is able to generate more economic value than corporate profits in the industry and when a competitor cannot mimic the benefits of the strategy or to see how the company is superior or not [13].

There needs to be a measured value as seen through the success of the company or the financial aspects of the measurable aspects. Similarly, research conducted by Ramadan (2012) found that sustainable competitive advantage can be measured by outcomes, namely a sales presentation of new products, presentations inventory costs, and presentation productivity growth, because the three indicators reflect the company with high profit and the ability to adapt quickly [14].

To gain a competitive advantage, there are two categories of resource needed, tangible and intangible assets. Intangible assets consist of resources and capabilities [15]. Capability is derived from the human resources as well as the organization's activities. However, it requires talented human resources which are obtained the company through talent management strategies because talent management has a VRIN characteristic [16].

Lewis and Heckman (2006), stated that there are three key concepts of talent management. Firstly, it is the replacement of the practice of human resource management. Secondly, it is the development of the talent pool that focuses on meeting the needs of employees. Third, it focuses on how to manage the download / talented employees [17]. Moreover, Powell and Lubitsh (2007), found five talent management perspective which differentiates between one organization to another organization, such as: process, culture, competition, development, and human resource planning [18].

The results of several previous studies suggested that, by using talent management, the company will get human resources with potential performance, high level of employee engagement which significantly reduces turnover giving added value and positive and significant impact to the competitive advantage of the companies [19] [20].

Talent management can produce unique and also form the capability of employees in order to achieve the goals of the company through the functions of human resource management in the withdrawal, developing, and maintaining process. In carrying out its activities, talent management makes the company capable in finding, retaining and developing their talented human resources [20] [21]. This is difficult to be imitated by another company, although it has the same human resources, how to manage them will differ one and another. Talent management activities cannot be separated from the function of human resource management [9] [22].

Therefore, Armstrong (2006) defines talent management as a process that is crucial to ensure the quality and quantity of people or employees needed for current and future business activities. It is a series of integrated activities to ensure the organization to be more attractive, survive, motivated and undertake the development of the talented people for recent and future need. It can be concluded that the talent is one of the core resources for the organization [9].

Because the output of rattan furniture is a physical product, it will be easy and quick to be imitated by competitors, but what distinguishes it is the human resources such as artisans and their employees as well as the inherent attributes of the company as a combination that will give the company an ability to face the competition. All of these are difficult to be replaced and emulated in quick time. The selection of talented human resources is the implication of a company that has a culture, human resource systems and innovative human resources routines so that it becomes unique to the company. This process is difficult to be replicated and implemented quickly by the company's competitors.

Based on the previous explanation, the writer is interested in studying more about the competitive advantage rattan furniture industry based on human resource management such as using talent management strategy in order to find out the effect of talent management on industry competitive advantage. It can be concluded that the hypothesis of the 
research is that the talent management has a positive influence on the competitive advantage of the rattan furniture industry.

Based on the explanation above, the indicators used is the competitive advantage of sales growth, profit growth, the growth of new products, and the productivity of employees.

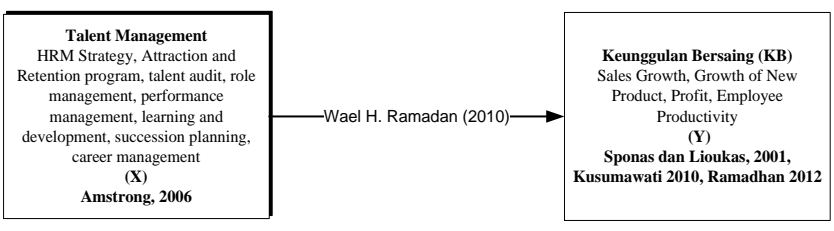

Fig. 1. Research Framework

The research framework's proposition is that there is an influence between talent management to competitive advantage. Talent management variables include HRM Strategy, Attraction and Retention program, talent audit, role management, performance management, learning and development, succession planning, career management. Competitive Advantage variables include Sales Growth, Growth of New Product, Profit, Employee Productivity.

\section{RESEARCH METHOD}

This Primary data were collected through a questionnaire survey, distribute to 70 furniture, rattan companies member ASMINDO Cirebon. Talent management measured using characteristic by Amstrong (2006) and competitive advantage measured using 4 indicators by Sponas and Lioukas, 2001, Kusumawati 2010, Ramadhan 2012.

Unit analysis for this research are companies who members ASMINDO Cirebon by 85 companies. And only 70 companies being sampled using Slovin and Slovilla formula with error 5\% with 4 people each companies for respondent, such as designer, craftsman, 2 employees from Human resources department and export-import department. The data is categorized into three criteria: low, moderate, and high. Furthermore, the data are analyzed using simple regression analysis.

\section{RESULT AND DISCUSSION}

From descriptive analysis, statistics with $95 \%$ confidence level, it is found that, generally, talent management strategy is in the average category. The highest indicators are motivation and recognition, employee engagement, relationship between the employee and their role, career planning for talented people, internal recruitment.

And the lowest indicators are comfortable to work, change to evolve, and leadership succession. It indicates the companies have not been able to create enough work convenience for its employees. Show as a Figure. 2

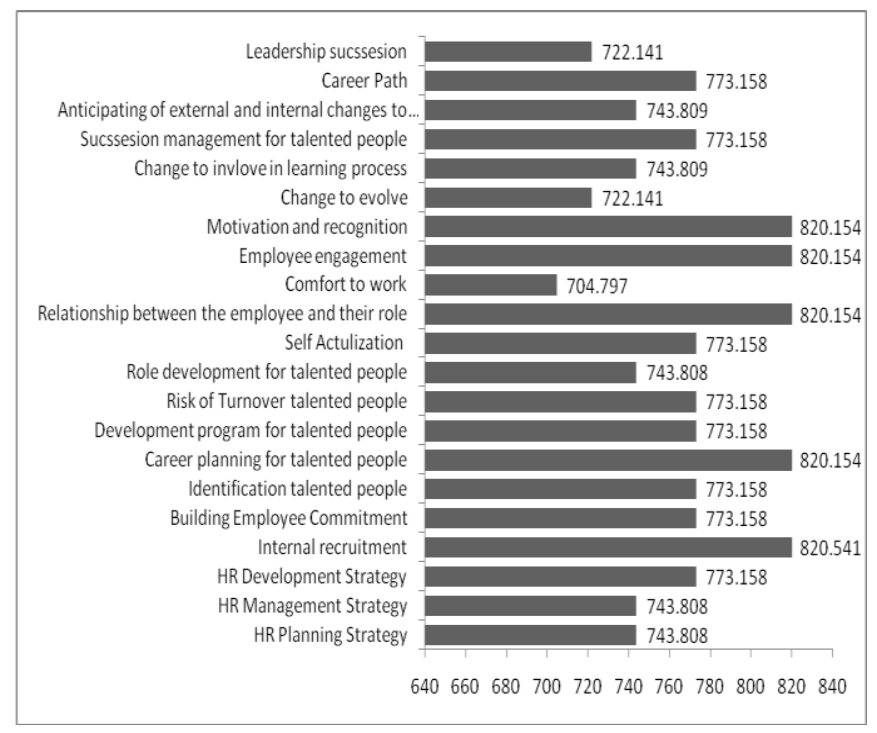

Fig. 2. Total Indicators of Talent Management

The level of Competitive advantage rattan furniture industry Cirebon categorized enough who became from employee productivities. Show as Figure 3. It means the level of competitive advantage rattan furniture industry Cirebon more focus on employee productivity, because of their activities based on demand and subcontracting craftsman. Associated with resource based view perspective, indicates that the level competitive advantage rattan furniture industry Cirebon focuses on internal resources especially human resource management through increased employee productivity. In the end, human resources more productive will be affected to financial criteria such as no inventory cost and zero defects. So rattan furniture industry Cirebon that focuses on the growth rate of productivity of employees, the growth rate of new products, and the growth rate of new sales to increase profitability.

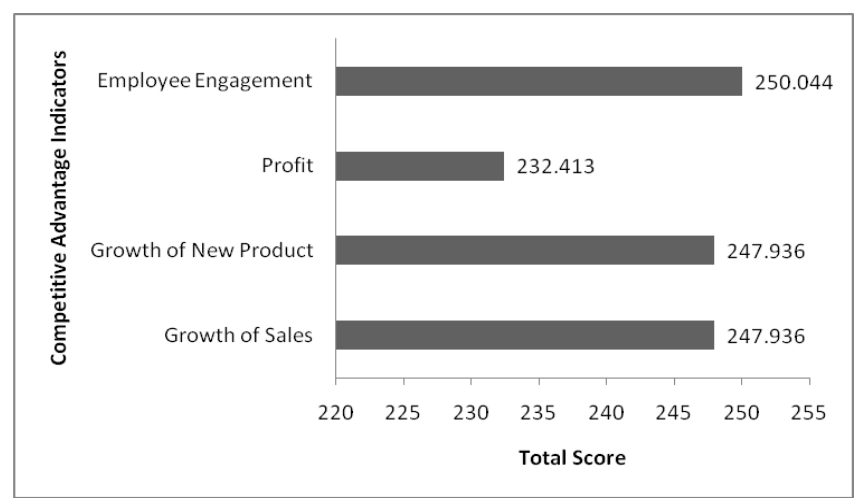

Fig. 3. Score Total Competitive Advantage Indicators

Based on the data processing result, the level of competitive advantage of rattan furniture industry Cirebon has positively and significantly influenced by the level of talent management of $41.2 \%$. This is because the significance value of 0.000 which is smaller than the significance level was set at 0.05 and t test $6.896(6.896>1.98)$. Show as Table 1 . 


\begin{tabular}{|c|c|c|c|c|c|}
\hline \multirow[b]{2}{*}{ Model } & \multicolumn{2}{|c|}{$\begin{array}{l}\text { Unstandardized } \\
\text { Coefficients }\end{array}$} & \multirow{2}{*}{\begin{tabular}{|c|}
$\begin{array}{c}\text { Standardiz } \\
\text { ed } \\
\text { Coefficients }\end{array}$ \\
Beta \\
\end{tabular}} & \multirow[b]{2}{*}{$\mathrm{t}$} & \multirow[b]{2}{*}{ Sig. } \\
\hline & $\bar{B}$ & Std. Error & & & \\
\hline $\begin{array}{l}1 \text { (Constant) } \\
\mathrm{x}\end{array}$ & $\begin{array}{r}0.144 \\
0.18\end{array}$ & $\begin{array}{l}2.016 \\
0.026\end{array}$ & 0.642 & $\begin{array}{l}0.071 \\
6.896\end{array}$ & 0.943 \\
\hline
\end{tabular}

These results can prove the statement raised by Hanif, Masood, Tariq, and Azhar (2012) which has been doing a theoretical study of a variety of research and literature that the strategy of talent management into a source of sustainable competitive advantage because every dimension of talent management has VIRN (valuable, inimitable, rare, and nonsubstitutable) characteristics. Rare its mean has a talent pool to have a potential candidate to produce more effective and optimal result. And transformation process is human development activities for the all candidates at talent pool means valuable. So hard to imitate with others quickly because has integrated with all process and procedure with human resource management function. Not surprisingly, research conducted by Ramadan (2012) suggested that the talent management can provide a positive and significant impact on competitive advantage of a company, because the talent management is a process that is integrated into the corporate culture in identifying strategic position as well as potential employees who assured the availability of human capital appropriate in order to achieve the company's goals faster.

\section{CONCLUSION AND SUGGESTION}

The result showed that talent management in rattan furniture industry in Cirebon is in average categories and have not been able to create enough work convenience for its employees, which means that the company has not fully implemented the strategy. And level of competitive advantage of rattan furniture industry categorized average or sufficient category that focuses on the growth rate of productivity of employees. And the level of competitive advantage of rattan furniture industry Cirebon has positively and significantly influenced by the level of talent management.

Therefore, it is suggested to do further research on the factors that influence, talent management, especially in the rattan furniture industry. And need to be conducted in order to measurably competitive advantage use resource based view indicators or VIRN.

\section{ACKNOWLEDGEMENT}

This research project would not have been possible without support by Mrs. Anita as Secretary of ASMINDO Cirebon. And also gratefully acknowledge for Dr. Hilmiana, SE.,MBA dan Meri Citra Sondari, SE.,MM. for helpful comments and suggestions.

\section{REFERENCES}

[1] KPPU "Positioning Paper KPPU terhadap KEBIJAKAN EKSPOR ROTAN 2012

[2] Ministry of Industry, 2010

[3] ASMINDO Report 2010

[4] KPPU "Positioning Paper KPPU terhadap KEBIJAKAN EKSPOR ROTAN 2012

[5] Barney, Jay B dan Delwyn N.Clark. 2007. Resource-Based Theory: Creating and Sustaining Competitive Advantage. UK: Oxford University Press.

[6] Prahalad, C.K dan Gary Hamel. 1990. The Core Competence of The Corporation. Harvard Business Review. p.90.

[7] Barney, Jay B dan Delwyn N.Clark. 2007. Resource-Based Theory: Creating and Sustaining Competitive Advantage. UK: Oxford University Press.

[8] Carmeli, Abraham. 2004. Asseing Core Intangible Resources. European Management Journal Vol.22, No.1, p.110-122

[9] Amstrong, Michael. 2006. A Handbook Human Resources Management Practice. 10th Ed. London and Philadelphia: Kogan Page.

[10] Spanos, Y.E. and Lioukas. S.2001. An Examination into the causal logic of rent generation:contrasting Porters competitive strategy framework and theresources-based perspective. Strategic Management Journal, 22(10), 970-934

[11] Kusumawati, R. 2010. Pengaruh Karakteristik Pimpinandan Inovasi Produk Baru Terhadap Kinerja Perusahaan Untuk Mencapai Keunggulan Bersaing Berkelanjutan. AKSES: JUrnal Ekonomi dan Bisnis. Vol.5 No.9 April, p.53-64

[12] Ferdinand, Augusty. 2003. Thesis. Strategic Pathways Towards Sustainable Competitive Advantage. unpublished

[13] Barney, Jay B dan Delwyn N.Clark. 2007. Resource-Based Theory: Creating and Sustaining Competitive Advantage. UK: Oxford University Press.

[14] Wael H. Ramadan. 2012. "The Influence of Talent Management on Sustainable Competitive Advantage o Small and Medium Sized Establishments". E-Leader Berlin.

[15] Hall, Richard. 1992. The Strategic Analysis of Intangible Resources. Strategic Management Journal, Vol. 13, Issue 2. P.134-135.

[16] Hanif. Rahmat;Arif Masood;Samra Tariq;Dr.Sarvar Azhar. 2012.Strateguc Talent Management as Source of Competitive Advantage "Talent Competitiveness Framework". SSRN

[17] Lewis, R. E. \& Heckamn, R.J. 2006. Talent Management: A Critica Review. Human Resources Management Review, 16, 139-154.

[18] Powell, M \& Lubitsh, G. 2007. Courage in the Face of Extraordinary Talent. Strategic HR Review, 6(5):24

[19] Bano, Schehar; Dr. Muhamamd Aslam Khan; Qazi Habib Ur Rehman; Asad Afzal Humayoun. 2011. SCHEMATIZING TALENT MANAGEMENT, A CORE BUSINESS ISSUE.

[20] Ahmad Yousef Areiqat, Tawfiq Abdelhadi, Hussien Ahmad Al-Taraweh. 2010. Talent Management as a Strategy Practice of Human Resources Management to Improve Human Performance. Interdisiplinary Journal of Contemporary Research Busniess. June 2010 Vol.2, No.2. Ulrich's.

[21] Mucha, Rochelle Turoff . 2004. The Art and Science of Talent Management.. Organizational Development Journal; Winter 2004; 22 , 4;ABI/INFORM Complete pg.96.

[22] Cheese, P; Robert J Thomas and Elizabeth Craig. 2007. The Talen Powered Organization "Strategies for Globalization, Talent Management and High Performance". Kogan Page. London and Philadelphia. 